\title{
On the Relationship Between Serum Apelin Levels and Some Parameters Related to Oxidative Stress and Energy Metabolism in Obese and Non-Obese
}

\author{
Fatma Betül Daşkın Fakıoğlư ${ }^{1}$, Türkan Yiğitbaşı ${ }^{1}$, Nesrin Emekli1* \\ ${ }^{1}$ Division of Biochemistry Faculty of Medicine, Medipol University, Istanbul, Turkey
}

\begin{abstract}
Adipose tissue plays an important role in energy balance by secretion of various adipokines. Obesity is excessive fat accumulation in the body. The aim of this study is to examine the association of apelin, an adipokine secreted from fat tissue, with antioxidant system, glucose and lipid parameters in obese and control cases. After approval has been taken from the Ethics Committee, 61 obese and 24 control people were included in the study. The ages in the study group ranges between 18 and 75. The body mass index (BMI) is >24.9 in obese people, and it ranges between 18.5 - 24.9 in control cases. Apelin was calculated using the ELISA method, total oxidant and total antioxidant levels were calculated using the colorimetric method, fasting blood glucose, insulin, TG, LDL and HDL levels were calculated using the photometric method, insulin resistance was calculated using the HOMA-IR method. Serum apelin levels were not found to differ between obese and control groups ( $>>0.05)$. Total antioxidant level (TAS) decreased in the obese group $(\mathrm{p}<\mathrm{0.001})$ while total oxidant level (TOS) remained the same. The Oxidative Stres Index (OSI) increased ( $p<0.001)$ in the obese group. In the obese group, glucose and insulin resistance were high $(\mathrm{p}<0.05)$ while serum insulin levels were the same as in the control group ( $\mathrm{p}>0.05$ ). In our study group, lipid parameters did not exhibit any difference in the obese and control groups. There was a significant relationship at $\mathrm{p}<0.05$ level between triglyceride values in the control and obese case groups, while there were no significant differences among other lipid parameters.
\end{abstract}

As a result; we think that further studies are needed to understand the effect of apelin, which is released from fat tissue and is active in energy metabolism.

Keywords: Obesity, apelin, oxidative stress, adipose tissue

\section{INTRODUCTION}

Studies show that health expenditures for obesity are higher than health expenditures for smoking. ${ }^{1,2}$ The pathophysiology of obesity is related to a large number of factors secreted from enlarged fat cells. Increased release of free fatty acid increases fatty acid intake into liver and peripheral tissues. Insulin degradation in the liver is diminished and the level of insulin in the circulation increases.

*Corresponding author: Nesrin Emekli, e-mail: nemekli@medipol.edu.tr (Received 3 July 2017, accepted 5 August 2017) 
Storage of fatty acids in the liver plays a role in the development of insulin resistance. In this way, other organs start to be affected by the change in insulin metabolism and undesirable metabolic changes occur. ${ }^{3,4}$ For many years, adipose tissue was known as an inert energy store, where triglycerides were stored and, when needed, released fatty acids into the blood. However, especially since the last 20 years, it has been shown that fat tissue works as an active endocrine organ, is metabolically important and that the cytokines (adipokines) released in here are signal transmitting molecules. ${ }^{1,2,5}$

Adipokines released from adipose tissue circulate like hormones and perform various functions in tissues of the immune system, brain, liver and adipose tissue. Pathologies such as obesity, Type 2 diabetes, inflammation and cardiovascular diseases are seen in dysregulation of adipokines. ${ }^{6}$ In recent years, it is known that in the relationship between inflammation and Type 2 diabetes and insulin resistance, adipose tissue has an effective function. Various adipokines, such as leptin and apelin, released from adipose tissue as well as from other tissues, can be activated by complex mechanisms in fasting regulation and energy balance. Insulin resistance refers to impaired biologic response to insulin that is either externally applied or internally secreted. Insulin sensitivity is influenced by many factors such as age, weight, especially abdominal body fat, physical activity and drug intake. Fat distribution for cardiovascular diseases is a major risk factor. With a competitive inhibition, free fatty acid (FFA) prevents glucose from entering into the cell. FFA slowing of peripheral glucose utilization causes insulin resistance and hyperinsulinemia. ${ }^{2,3,7-9}$

Apelin is synthesized in adipose and other tissues in humans and rats and there are apelin receptors in various tissues. ${ }^{10}$ Apelin, a cytokine that joined the adipokine family in 1998, is also considered as a hormone. It has isoforms in various organs. It also exists in the plasma. It is known to have endocrine and neurotransmitter effects Apelin expression in fat cells is suppressed by starvation and has similar effects on insulin following feeding. ${ }^{11,12}$ It has been reported that apelin gene expression in fat tissue is stimulated by insulin and TNF- $\alpha$ Apelin is both synthesized and secreted in fat tissue. ${ }^{13}$ Experimental animal studies have shown increased skeletal glucose use and reduced plasma glucose levels after apelin injection. Increased apelin with hyperinsulinemia was observed in obese subjects. ${ }^{14-16}$

There are studies reporting that the antioxidant capacity is impaired in obesity. ${ }^{17,18}$ Sudden or excessive oxygen entrance into the organism due to various metabolic reasons, antioxidant defense system insufficiency or oxidant-antioxidant balance to gravitate towards the oxidant side, which then leads to occurrence of oxidative stress. This situation could also be caused by formation of free radicals or insufficient antioxidant activities, either of which indicates increase of free fatty acids among active molecules. ${ }^{19-22}$ 
The purpose of this study is to examine apelin, which is defined as an important adipokine, considered as a significant health problem that has gradually been more frequently encountered in the world, in terms of diabetes, insulin resistance and dyslipidaemia and portray how these parameters work with total oxidant/antioxidant status.

\section{MATERIALS AND METHODS}

This study was supported by İstanbul Medipol University Scientific Research Projects by the project no: 86770134-604/101.

\section{Study Design and Data Collection}

Included in the study were 24 control groups made up of 13 male and 11 female persons and 61 patient groups made up of 37 male and 24 female persons, all of which applied to the Medipol University's Mega Hospital Laboratory between September-October 2015. The people with $18.5 \leq \mathrm{BMI} \leq 24.9 ; \mathrm{kg} / \mathrm{m}^{2}$ were considered normal weight and the people with $\mathrm{BMI}>30 \mathrm{~kg} / \mathrm{m}^{2}$ were considered obese, and these persons were accordingly split into two groups (Table 1).

Table 1. The demographic measurement values of control and obese group.

\begin{tabular}{|c|c|c|}
\hline & Control Group (Mean \pm SD) & Obese Group (Mean \pm SD) \\
\hline Height(m) & $1,70 \pm 0,05$ & $1,70 \pm 0,07$ \\
\hline Age (year) & $37,6 \pm 11,22$ & $48,74 \pm 12,5$ \\
\hline Body weight $\mathbf{( k g )}$ & $69,5 \pm 6,98$ & $96,88 \pm 16,6$ \\
\hline BMI (kg/m $\left.\mathbf{m}^{2}\right)$ & $23,52 \pm 0,89$ & $33,76 \pm 6,15$ \\
\hline
\end{tabular}

$\mathrm{BMI}=$ Body Mass Index

\section{Study Exclusion Criteria}

Exclusion criteria were; being younger than 18 years and older than 75 years, smoking hypertension, cardiac diseases, osteoarthrosis, cancer, polycystic ovary disease and inflammatory and infectious diseases. The study started after the approval of Medipol University Ethics Board. All the subjects were informed about the study and their approved consent forms were received.

\section{Blood Collection and Storage}

After 8 hours of fasting, the blood drawn into yellow capped flat tubes was centrifuged at 2400 rpm for 10 minutes in Medipol University Biochemistry Laboratory to separate serum. The separated serum was moved into eppendorf tubes and then stored there at $-80{ }^{\circ} \mathrm{C}$ until the date of the study. 


\section{Methods Used}

Apelin was calculated using the ELISA method, total oxidant and total antioxidant levels were calculated using the colorimetric method, glucose, insulin, TG, LDL, HDL levels were calculated using the photometric method, insulin resistance was calculated using the HOMA-IR method and oxidative stress index was calculated using the formula given below: OSI $=\left[\left(\mathrm{TOS}, \mu \mathrm{mol} \mathrm{H}_{2} \mathrm{O}_{2}\right.\right.$ equivalent/l) / (TAS, $\mu$ mol Trolox equivalent/l)] x100.

\section{Statistical Analysis}

SPSS software was used in the study and variables were defined through standard deviation. Mann-Whitey U test was used in comparing averages which do not exhibit a normal distribution and Student t test was used in comparing averages which exhibit a normal distribution. One-Way ANOVA was used to compare averages of more than two groups and to interpret the differences between the subgroups in variables exhibiting differences. $P$-value $<0.05$ were accepted as significant.

\section{RESULTS}

The study findings are summarized in table 2.

Table 2. Laboratory findings of control and obese group.

\begin{tabular}{|c|c|c|c|}
\hline & $\begin{array}{c}\text { Control group } \\
\text { (Mean } \pm S D)\end{array}$ & $\begin{array}{c}\text { Obese group } \\
\text { (Mean } \pm S D \text { ) }\end{array}$ & $P^{*}$ \\
\hline Apelin $(\mathrm{pg} / \mathrm{mL})$ & $916,29 \pm 139,07$ & $902 \pm 132$ & 0,676 \\
\hline TAS ( $\mu$ molTroloxEquiv./L) & $0,92 \pm 0,11$ & $0,81 \pm 0,13$ & $<0,05$ \\
\hline $\mathrm{TOS}\left(\mu \mathrm{mol} \mathrm{H} \mathrm{H}_{2} \mathrm{O}_{2}\right.$ Equiv./L) & $26,96 \pm 5,49$ & $28,26 \pm 6,31$ & 0,386 \\
\hline OSI(AU) & $2,92 \pm 0,62$ & $3,56 \pm 0,86$ & $<0,05$ \\
\hline $\mathrm{FBG}(\mathrm{mg} / \mathrm{dL})$ & $103,44 \pm 15,87$ & $151,96 \pm 69,05$ & $<0,05$ \\
\hline Insulin( $\mu \mathrm{U} / \mathrm{mI})$ & $10,83 \pm 3,86$ & $17,21 \pm 20,4$ & 0,072 \\
\hline Insulin Resistance & $2,76 \pm 1,00$ & $6,40 \pm 7,46$ & 0,05 \\
\hline $\mathrm{HDL}(\mathrm{mg} / \mathrm{dL})$ & $53,22 \pm 17,82$ & $47,65 \pm 13,52$ & 0,149 \\
\hline LDL(mg/dL) & $119,35 \pm 34,45$ & $121,98 \pm 37,88$ & 0,768 \\
\hline $\mathrm{TG}(\mathrm{mg} / \mathrm{dL})$ & $126,14 \pm 82,92$ & $158,13 \pm 85,36$ & 0,033 \\
\hline $\mathrm{TC}(\mathrm{mg} / \mathrm{dL})$ & $195,46 \pm 41,36$ & $198,35 \pm 40,99$ & 0,771 \\
\hline
\end{tabular}

*P-value < 0.05 for $\mathrm{t}$ test. Abbreviations: TAS, total antioxidant response; TOS, total oxidant status; OSI, oxidative stress index value; AU, Arbitrary unit; FBG; fasting blood glucose; TC, total cholesterol 
There was no significant difference between apelin values in the control and obese case groups. When apelin's relation to other parameters was studied; no significant correlation was observed between the control and obese group in terms of any parameters.

TAS values were significantly lower in the obese group than in the control group ( $\mathrm{p}<0.05)$. When TAS relation to other parameters was studied; TAS and BMI ( $\mathrm{r}:-0.45, \mathrm{p}<0.05$ ) and TAS and OSI ( $\mathrm{r}:-0.47, \mathrm{p}<0.05$ ) showed weak negative correlations in all cases.

There was no significant difference between total oxidant values in the control and obese case groups. When the relationship of TOS with other parameters were studied, a positive relation was found between TOS and OSI (r: $0.77, \mathrm{p}<$ o.05) TOS and TG (r: 0.52, p < 0.05) TOS and insulin (r: 0.34, p<0.05), TOS and $\mathrm{HbA}_{1} \mathrm{c}(\mathrm{r}: 0.23, \mathrm{p}<0.05)$, a negative correlation was observed between TOS values and HDL (r: -0.34, $\mathrm{p}<0.05)$.

OSI values were significantly higher in the obese group compared to the control group ( $\mathrm{p}<0.05$ ). When the relationship of OSI with other parameters were studied, a positive relation was found between OSI and TG (r: 0.33, p< 0.05) OSI and insuline ( $\mathrm{r}: 0.37, \mathrm{p}<0.05$ ).

FBG values of the obese group are higher than that of the control group ( $\mathrm{p}<0.05)$. No significant difference was found between insulin values of the control and obese case groups but insulin resistance was seen in the obese group $(\mathrm{p}<0.05)$.

When the relationship of FBG with other parameters were studied, a positive relation was found between FBG and TG (r: 0.31, p < 0.05) FBG and $\mathrm{HbA}_{1} \mathrm{c}$ (r: $0.75, \mathrm{p}<0.05)$ a negative correlation was observed between FBGvalues and HDL (r: $-0.23, \mathrm{p}<0.05)$.

TG values were significantly higher in the obese group compared to the control group ( $\mathrm{p}<0.05$ ) while there were no significant differences among other lipid parameters and a positive correlation was observed between $\mathrm{TG}$ values and $\mathrm{HbA}_{1} \mathrm{c}$ (r: 0.29, p<0.05).

\section{DISCUSSION}

Obesity is the result of the accumulation of triglycerides in adiposites that is, the intake of excess calories from the energy used. Fatty tissue is active in insulin sensitivity and energy balance by releasing various adipokines as an endocrine organ. Obesity-related pathologies are seen because excess fat tissue, also referred to as adipose tissue, causes modifications in adipokines. Dyslipidemia seen in obesity is one of the issues that are emphasized nowadays because it 
leads to cardiovascular diseases and atherosclerosis. Having the waist circumference and waist / hip ratio above the reference values causes the android obesity, which leads to impaired adipokine balance. Obesity is examined in every direction, considering the future of the world and our country. ${ }^{23,24}$

Apelin is synthesized and secreted in some tissues as well as in fat tissue. Apelin upregulation has been observed in obese and hyperinsulinemic humans and mice. Despite these facts, however, there are still many unknowns. Do we have opelin in all body cells? Or can it be effective in regulation only in certain organs? This is one of the unknowns of apelin. . $5,26,27$

Based on this information, we measured the apelin levels in the obese people we included in our study group. We also measured FBG, insulin level, insulin resistance, TG, TC, HDL-C and LDL-C levels in order to make evaluations in terms of carbohydrate metabolism and lipid metabolism. We measured TAS, TOS and OSI levels to understand the antioxidant and oxidant levels of the cases we included in the study group.

In 61 obese cases and 24 control groups included in our study group, apelin values did not show a significant difference despite FBG and insulin resistance were high.

The most characteristic feature of obesity and Type 2 diabetes, which develops with obesity, is that the insulin resistance develops and the insulin resistance increases parallel to the body mass index. Adipokines, such as apelin released from fat tissue, are effective in energy balance and glucose metabolism, attracting attention to increased adipokines with fat mass.

Cavallo et al. measured serum Apelin levels in 119 Type 2 diabetes, 113 Type 1 diabetes and 137 non-diabetic groups by Elisa method and found apelin levels higher in Type 2 diabetic patients rather than in Type 1 diabetic patients. ${ }^{14}$ Researchers found a significant decrease in serum apelin levels after bariatric surgery in obese subjects with Type 2 diabetes in the same study group. The results from researchers' work indicate that the relationship between Type 2 diabetes and apelin is related to glucose balance, but not to obesity and other metabolic abnormalities. The researchers found no association between HOMA-IR and apelin-12 amount in the serum. In our study, apelin levels were not changed. Cavallo et al. reported that apelin levels were increased in relation to glucose level, not obesity. ${ }^{14}$ This is consistent with our study.

Guo et al. reported that apelin activates P13-kinase phosphodiesterase leading to decreased apelin in pancreatic $\beta$ cells, while Erdem at al. reported that serum apelin levels in newly diagnosed diabetes patients decreased. ${ }^{15,27}$ Similarly, there was a decrease in serum apelin levels in Type 2 diabetes in Chinese population..$^{28}$ 
On the other hand, children with Type 1 diabetes had high serum apelin levels. ${ }^{29}$ Yue et al. reported that apelin is a necessary adipokine in insulin sensitivity, but studies on the effect of apelin on impaired glucose metabolism are contradictory. ${ }^{30}$ Boucher et al. found that apelin levels were high in hyperinsulinemic mice, whereas apelin levels were normal in persons with normal insulin levels. ${ }^{31}$ In our study, the insulin values in the obese group were within the reference ranges and there was no change in apelin levels. This is consistent with Boucher et al. findings. ${ }^{31}$

The regulation of energy metabolism is a complex mechanism. The imbalances in this mechanism cause diseases that obesity causes. Apelin is one of the peptides that regulate energy metabolism. Heinnonen et al. reported that apelin levels correlated positively with BMI. ${ }^{2}$ In our study, BMI was significantly different in normal and control groups, but there was no correlation between apelin levels and BMI index.

Dray et al. have shown that apelin injection in rats has a strong glucose-lowering effect and that it increases glucose utilization in skeletal muscle and adipose tissue. ${ }^{16}$ In summary, researchers have found that apelin improves glucose tolerance and increases glucose utilization in obese and insulin resistant rats. With this feature apelin appears to be a promising adipokine in the correction of insulin resistance.

In the Söylemez et al. study, 87 individiduals selected among applications to cardiology polyclinic were separated as normal weight (group $1, \mathrm{n}=29$ ) based on BMI between 19-25 kg/m², overweight (group 2, $\mathrm{n}=29$ ) based on BMI between $25-30 \mathrm{~kg} / \mathrm{m}^{2}$ and obese (group 3, $\mathrm{n}=29$ ) based on BMI over $30 \mathrm{~kg} / \mathrm{m}^{2} .^{32}$ Plasma leptin levels correlated with TAS, TOS and OSI, but no relation was found between adiponectin levels.

Bircan et al. showed that apelin-13 applied after renal ischemia/reperfusion increased the antioxidant enzyme activity in a dose dependent manner, prevented the lipid oxidation and improved the renal functions. ${ }^{33}$ Based on these results, researchers thought that apelin could decrease oxidative stres.

In our study, the TAS values of the obese group were low and the OSI values were found to be higher than those of the control group, but there was no significant correlation between apelin values and TAS, TOS and OSI values.

In conclusion, we think that further studies are needed to understand the effect of apelin, which is released from fat tissue and is active in energy metabolism. 


\section{REFERENCES}

1. Yiğitbaşı T, Emekli N. Obezite biyokimyası. İçinde: Klinik Biyokimya, Editörler: Emekli \& Yiğitbaşı, Akademi Basım Yayın, Yayımcı Nobel Tıp Kitabevleri Tic. Ltd. Şti. 2015, 311-322.

2. Haslam D, Sattar N, Lean M. ABC of obesity: obesity time to wake up. British Medical Journal. 2014, 333(7569), 640-642.

3. İslamoğlu Y, Koplay M, Sunay S, Açıkel M. Obezite ve metabolik sendrom. Tip Araştırmaları Dergisi, 2008, 6(3), 168-174.

4. Knights A.J., Funnell A.P., Pearson R.C., Crossley M., Bell-Anderson K.S. Adipokines and insulin action: A sensitive issue. Adipocyte. 2014, 3(2), 88-89.

5. Fernández-Sánchez A, Madrigal-Santillán E, Mirandeli Bautista M, Esquivel-Soto J, MoralesGonzález A, Esquivel-Chirino C Inflammation, Oxidative Stress, and Obesit. Int. J. Mol. Sci. 2011, 12(5), 3117-3132.

6. Sikaris K. A. The clinical biochemistry of obesity. Clin Biochem Rev. 2oo4, 25, 165- 173.

7. Li L, Yang G, Li Q, Tang Y, Yang M, Yang H, Li K. Changes and relations of circulating visfatin, apelin, and resistin levels in normal, impaired glucose tolerance, and type 2 diabetic subjects. Exp Clin Endocrinol Diabetes. 2006, 114(10), 544-548.

8. Yiğitbaşı T, Baskın Y, Afacan G, Harmande A. Obez hastalarda büyüme hormonu, leptin, amilin, glukagon benzeri peptid 1 seviyeleri ile insülin direnci arasındaki ilişki. Türk Biyokimya Dergisi, 2010, 35, 177-182.

9. Reinehra T., Woelfleb J., Rothic C. L. Lack of association between apelin, insulin resistance, cardiovascular risk factors and obesity in children. Metabolism. 2011, 6o(9), 1349-1354.

10. Laurel C.I., Dray C, Attone C, Dubarc T, Knauf C, Valet P. Apelin diabetes and obesity. Endocrin. 2011, 4O, 1-9.

11. Telegdy G, Adamik A, Jaszberenyi M. Involvement of neurotransmitters in the action of apelin 13 on passive avoidance learning in mice. Peptides. 2013, 39, 171-174.

12. Heinonen M.V., Purhomen A.K., Miettinen P, Pakkönen M, Pirinen E, Alhava E, Akeman K, Herzig K.H. Apelin orexin-A and leptin plasma levels in morbid obezity and effect of gastric banding. Regulatory Peptides. 2005, 130(1-2), 7-13.

13. Alataş E.T., Kökçam İ: Psoriasis vulgarisli hastalarda adiponectin leptin ve apelin düzeylerinin araştırılması, Dicle Tip Dergisi, 2014, 41(1), 144-150.

14. Cavello MG, Sentinelli F, Barchetta I, Costantino C, Incani M, Perra L et al. Altered glucose homeostasis is associated with increased serum apelin levels in type 2 diabetes mellitus. PloS ONE. 2012, 7(12), e51236.

15. Erdem G, Doğru T, Taşc1, I, Sönmez A, Tapan S. Low plasma apelin levels in newly diagnosed type 2 diabetes mellitus. Exp Clin Endocrinol Diabetes. 2oo8, 116, 289-292.

16. Dray C, Knauf C, Daviaud D, Waget A, Boucher J, Buleon M. Apelin stimulates glucose utilization in normal and obese insulin resistant mice. Cell Metabolism, 2oo8, 8(5), 437-445.

17. Prazny M, Skrha J, Hilgertova J. Plasma malondialdehyde and obesity: Is there a relationship? Clin Chem Lab Med. 1999, 37, 1129-1133.

18. Özata M, Yllmaz İ, Merge M, Öktenli Ç, Aydın A. Hypozincemia and corrupted antioxidant capacity in male obesity. Türk $J$ Endocrinol Metab. 2oo3, 7, 21-26 (In Turkish). 
19. Alturfan E. I. Tükürüğün antioksidan kapasitesi. 309-322. İçinde: Tükürük: Histolojisi, Mikrobiyolojisi, Biyokimyası. Ed: Prof. Dr. Nesrin Emekli, Prof. Dr. Ayşen Yarat. Nobel Kitapevi. İstanbul, 2008.

20. Nelson DL, Michael MC. Lehninger Biyokimyanın İlkeleri. 3. Baskı 842-843, Çeviri Ed. Kılıç N. Palme Yayıncilık, 2005.

21. Yiğitbaşı T, Büyükuslu N. Reactive oxygen species and oxidative stress in obesity. Marmara Üniversitesi, Sağhk Bilimleri Enstitüsü Dergisi, 2015, 5(3), 197-203 (In Turkish).

22. Sandal S, Tekin S. A Hormone Released from Adipose Tissue: Apelin. İnönü Üniversitesi Sağllk Bilimleri Dergisi. 2013, 1, 55-62 (In Turkish).

23. Hall J.E., Hildebrandt D.A., Kuo J. Obesity hypertension: role of leptin and sympathetic nervous system. Am J Hypertens. 2001, 14(Suppl), 103-115.

24. Stamatakis E, Zaninotto P, Falaschetti E, Mindell J, Head J. Time trends in childhood and adolescent obesity in England from 1995 to 2007 and projections of prevalence to $2015 \mathrm{~J} \mathrm{Epi-}$ demiol Community Health. 2010, 64, 167-174.

25. Castan-Laurell I, Dray C, Knauf C, Kunduzova O, Valet P. Apelin a promisin target for type 2 diabetes treatment? Trends Endocrinol Metab. 2012, 23, 234-241.

26. Attane C, Foussal C, Le Gonidec S, Benani A, Daviaud D, Wanecq E. Apelin treatment increases complete fatty acid oxdation, mitochondrial oxidative capacity, and biogenesis in muscle of insulin resistant mice. Diabetes. 2012, 61, 310-320.

27. Guo L., Li Q., Wang W., Yu P, Pan H., Li P. Apelin inhibits insulin secretion in pancreatic beta cells by activation of P13 kinase-phospodiesterase 3B. Endocr Res. 2009, 34, 142-154.

28. Zhang Y., Shen C., Li X., Ren G., Fan X. Low plasma apelin in newly diagnosed type 2 diabetes in Chinese people. Diabetes Care. 2009, 32, e150.

29. Meral C., Tascilar E., Karademir F., Tanju I. A., Cekmez F., Ipcioglu O. M. Elevated plasma levels of apelin in children with type 1 diabetes mellitus. $J$ Pediatr Endocrinol Metab. 2010, 23, 497-502.

30. Yue P., Jin H., Aillaud M., Deng A. C., Azuma J., Asagami T. Apelin is necessary for the maintanance of insulin sensitivity. Am J Physiol Endocrinol Metab. 2010, 298(1), e59-67.

31. Boucher J., Masri B., Daviaud D., Gesta S., Guigne C., Mazzucotelli A. Apelin a newly identified adipokine up-regulated by insulin and obesity, Endocrinology. 2005, 146, 1764-1771.

32. Söylemez N., Demirbağ R., Sezen Y., Yıldız A., Akpınar O. Leptin and adiponectin levels according to body mass index and their relation with oxidative parameters. Anadolu Kardiyol Derg. 2010, 392(10), 391-396 (In Turkish).

33. Bircan B., Çakır M., Kırbağ S., Gül H. F. Effect of apelin hormone on renal ischemia/reperfusion induced oxidative damage in rats. Ren Fail. 2016, 38(7), 1122-1128. 